\title{
Infiltration and Inheritance of Chinese Traditional Culture in Environmental Art Design
}

\author{
Liu Kai*, Zhai Kunbei \\ College of Arts and Cultural Communication in Guangxi University of Science and Technology, \\ Guangxi, China, 545006
}

Keywords: Traditional Culture; Environmental Art Design; Cultural Inheritance.

Abstract: Chinese traditional culture is the crystallization of the wisdom of the Chinese nation and the concentrated embodiment of the customs and ideas of all nationalities. Its importance is self-evident. In the field of environmental art design, designers must learn and absorb various elements of traditional Chinese culture, and use, change and innovate them, to organically integrate modern and traditional, in order to achieve the goal of developing environmental art design and developing traditional culture. This paper talks about the traditional philosophical concept in environmental art design and explores the inheritance strategy and function of traditional culture in order to complete the in-depth analysis of the subject.

\section{Introduction}

Chinese traditional culture is the overall manifestation of the material heritage and ideological ideas accumulated by Chinese nationalities after a long history. It has not only a long history, broad and profound, but also distinct regional and national characteristics. With the rapid development of China's economy, designers have made tremendous contributions to improving the quality of life of the public. More and more environmental art works with traditional cultural characteristics appear around us. In the era of information explosion, it will be difficult for artistic creation to develop rapidly without the support of national traditional culture. At present, the penetration and inheritance of Chinese traditional culture in environmental art design has become a long-term issue for designers to study, to make it serve the society and benefit mankind ${ }^{[1]}$. Chinese traditional culture is mainly composed of ten elements, as shown in Table 1 below.

Table 1 Ten Elements of Chinese Traditional Culture

\begin{tabular}{|c|c|}
\hline No. & Element Name \\
\hline Element 1 & Totem auspicious \\
\hline Element 2 & Ideological Education Culture \\
\hline Element 3 & Music and Opera Culture \\
\hline Element 4 & Calligraphy and Painting, Paper-cut Art \\
\hline Element 5 & Clothing Wearing Culture \\
\hline Element 6 & Life culture \\
\hline Element 7 & Traditional Chinese medicine culture \\
\hline Element 8 & Chinese martial arts \\
\hline Element 9 & Chinese architecture and furniture decoration \\
\hline Element 10 & Culture of belief in gods and immortals \\
\hline
\end{tabular}




\section{Brief introduction of related concepts}

\subsection{Environmental Art Design}

In China, environmental art design is a relatively new discipline. In a narrow sense, it is an integral part of art design, but its work is more complex and involves a wider range than that of the construction industry. As a highly comprehensive art discipline, the design process of environmental art includes two parts: artistic scheme conception and spatial planning. In addition to environmental facilities planning, shape layout and decoration ${ }^{[2]}$, the use of design elements such as colour, material and light also plays an important role in the design. The diversification of functions makes the environmental art design have rich and colourful manifestations in form, which leaves a lot of room for the use of traditional elements. Under the influence of traditional culture, environmental art design integrates science and art, and realizes the unity of aesthetics and practicality.

\subsection{Traditional Culture}

As an ancient civilized country with a long history, China has a profound cultural heritage. The traditional elements handed down in the fields of architecture, costume, painting and calligraphy have integrated into an art treasure house for environmental art design to learn from and use. The traditional culture of the Chinese nation embodies the industriousness and wisdom of the people of all nationalities. It is the representative symbol of the national image and national interests. Among them $^{[3]}$, the traditional philosophy of adapting measures to local conditions and the unity of nature and man is one. Learning thought has a profound impact on the learning and creative activities of modern art designers.

\section{Traditional Philosophical Concepts in Modern Chinese Environmental Art Design}

\subsection{The Doctrine of the Mean}

Ancient Chinese philosophers attributed the development of culture to the drive of human spiritual quality, and the doctrine of the mean is one of the more important concepts. It covers a wide range of areas. The above mentioned "harmony between man and nature" is one of the branches. There are many nationalities in our country, and regional cultures in different historical periods also have different manifestations. In the face of so many architectural forms, making choices based on retaining the essence and completing the inheritance and recreation of tradition after blending into modern culture are reflecting the idea of "not going to extremes and impartiality" in the doctrine of the mean. Based on the combination of decorative elements, Chinese tradition also adheres to the principle of compromise. The concept of advocating the "mean" is still deeply reflected in the vision of modern Chinese environmental art design. From a rational philosophical point of view, the doctrine of the mean influences people's choice of aesthetic conception. Designers should grasp the traditional philosophical view represented by the doctrine of the mean and continue to implement the doctrine of the mean in environmental art design ${ }^{[4]}$.

\subsection{Adapt measures to local conditions}

The object of transformation of environmental art design is the internal and external environment of people's residence. Therefore, it has always been an important issue for designers to investigate and utilize the environment rationally. "Suitability" in "adapting to local conditions" refers to the 
design and planning work according to the natural environment's congenital conditions, to enable artificial buildings to integrate into nature, and even achieve the realm of harmony and unity. The natural environment is friendly and beautiful, it represents a real beauty, so it is deeply loved by artists. At the same time, the contradiction between man and the natural environment cannot be ignored. The traditional Chinese philosophical concept of adapting measures to local conditions is in line with the mainstream sustainable development concept of the contemporary era. Adhering to this idea in environmental art design can greatly alleviate the pollution and destruction caused by environmental transformation, and it can keep the relationship between human beings and nature in a balanced and rational level.

\section{The Main Role of Inheriting Traditional Culture in Environmental Art Design}

\subsection{Enhancing the Vitality of Artistic Works}

Artistic works have strong vitality because of their uniqueness. The traditional culture of the Chinese nation has undergone the baptism of time and precipitated in the changes of the times. It has distinct national characteristics. Therefore, the inheritance of traditional art in environmental art design is in line with the aesthetic needs of the Chinese people. In addition, learning and absorbing the essence of national traditional culture in design, considering national characteristics and regional customs, will expand the development space of environmental art design. By establishing the local traditional culture brand, we can also extend the traditional Chinese culture to the whole world. Only by standing on a larger platform can we have a broader vision of creation. Only in this way can environmental art and design works have a stronger vitality.

\subsection{Deepening the Harmony of Artistic Works}

The contemporary society advocates the concept of harmonious development, and China is also striving to build a more harmonious society. The environmental art design concept mentioned in the previous article is closely related to social harmony. The mainstream scientific development concept can also find a basis from these profound traditional philosophical ideas. Inheritance of traditional culture in environmental art design can not only alleviate the deterioration of ecological environment, but also deepen the harmony of art works. By learning and inheriting the traditional concept of harmony between man and nature, artists can gradually achieve a more harmonious state in environmental art design. National culture is an important support for environmental art and design works. Fully understanding this point will help China to enter the road of harmonious development more quickly, to benefit the public.

\section{Strategies for Infiltrating Traditional Culture into Environmental Art Design}

\subsection{Collecting and copying elements of traditional culture}

Traditional cultural elements have distinct national characteristics and charm. Facing the impact of the strong Western culture, the traditional culture of the Chinese nation is gradually losing in the change of time. In view of this situation, we should collect those symbolic visual elements and infiltrate them into modern environmental art design to protect traditional culture by copying traditional cultural elements. In the more in-depth processing work, environmental art design works should not only reflect the national temperament and spirit, but also have more diversified forms of expression. The reproduction of traditional graphics represents the transfer of artistic elements to new carriers. The renewal of visual language environment makes the original graphics retained, 
which fully reflects the flexibility of traditional cultural elements ${ }^{[5]}$.

\subsection{Alienation of Traditional Culture Elements}

After obtaining the original material of traditional cultural elements, simple collage and reproduction cannot fully meet the needs of environmental art design. We need to symmetry, reversal, tailoring and other alienation of these elements. Compared with simple elements

The way of extraction and alienation is more flexible. Designers can get more and richer visual elements from the original graphics, which will greatly enrich the material library of creators. Alienation is also a kind of reconstruction. Designing structures according to needs, rediscovering and displaying the beauty of traditional cultural elements, and trying to find more convenient junctions will fully mobilize people's thinking and help to form more complete modern environmental art design works.

\subsection{Combining Modernization}

In the ever-changing information age, new aesthetic concepts and aesthetic needs will appear every day. In order to make Chinese environmental art design adapt to this situation, the inheritance of traditional culture should keep its own uniqueness while incorporating some modern ways of thinking. The inheritance of traditional culture is an unchangeable theme, but its design process will inevitably be influenced by modern culture. With the continuous development of science and technology, environmental art design should incorporate more features of the trend of the times in order to adapt to changing social needs. Traditional culture has relatively fixed national characteristics, while modern culture has distinct characteristics of the times. Taking the advantages of the two and learning from each other can promote the development of environmental art design towards a more balanced and healthy direction. The combination of Chinese traditional culture and modern culture can not only reflect the long history of our country's culture, but also highlight the modern atmosphere of our country.

\section{Conclusion}

Cultural tradition embodies the spirit and character of a nation. Today, with the continuous development of environmental art design, we should integrate Chinese cultural tradition into the transformation of the environment. Under the guidance of the doctrine of the mean and the philosophical concept of adapting to local conditions, we should play the role of traditional elements by means of collection, alienation and innovation, enhance the vitality of artistic works, deepen the harmony of artistic works, and bring into play the practicability of environmental art design. Aesthetics promotes the healthy and sustainable development of environmental art design.

\section{References}

[1] Shen Lei. Inheritance and Infiltration of Regional Culture in Environmental Art Design [J].Think Tank Age, 2018 (28): 207-208.

[2] Qi E. Aesthetic Study of Environmental Art Design Based on the View of Tea Culture [J]. Fujian Tea, 2018,40 (02): 301-302.

[3] Wang Caibo. The infiltration and application of tea culture in modern environmental art design [J]. Fujian Tea, 2018, 40 (02): 448.

[4] Fan Yuqing. Traditional Cultural Conception in Modern Environmental Art Design [J]. Journal of Jilin Institute of Education, 2015, 31 (02): 146-147.

[5] Cheng Su'e. Infiltration of traditional national culture in Chinese art design [J]. Art Science and Technology, 2013, 26 (04): 253. 